SPECIAL ISSUE OF THE CONFERENCE WITH THE THEME "ENHANCING

ACADEMIC SUCCESS THROUGH THE INVOLVEMENT OF STUDENTS IN

QUALITY ASSURANCE AND PROMOTION IN HIGHER EDUCATION"

ORGANISED BY THE COUNCIL ON HIGHER EDUCATION IN FEBRUARY 2020

\title{
ENHANCING ACADEMIC SUCCESS THROUGH THE INVOLVEMENT OF STUDENTS IN QUALITY ASSURANCE AND PROMOTION IN HIGHER EDUCATION: A SYNOPSIS
}

\author{
A. Saidi \\ Research, Monitoring \& Advice \\ Council on Higher Education \\ Pretoria, South Africa \\ e-mail: Saidi.A@che.ac.za
}

\section{ABSTRACT}

One of the hallmarks of the democratisation of higher education is the involvement of students in the entire higher education delivery value chain. Global literature demonstrates a positive causal relationship between the involvement of students in the higher education delivery value chain and academic success. The article contends that, since quality assurance and promotion are acknowledged as integral components of the higher education delivery value chain, the involvement of students in quality assurance and promotion processes at the institutional and national levels can contribute positively towards enhancing academic success for students. The post-apartheid policies on higher education envisioned a transformed, effective and efficient higher education system, characterised by, among others, expanding access and improving student success. Unfortunately, while access has been expanding substantially, academic success of students has not improved significantly. This state of affairs requires that all stakeholders should have their hands on deck to contribute, through their diverse work activities, towards improving academic success of students. It is within this context that the CHE organised a conference on the theme: "Enhancing Academic Success through the Involvement of Students in Quality Assurance and Promotion in Higher Education". This article provides a synopsis of the contribution of the conference to the discourse on enhancing the academic success through the involvement of students in quality assurance and promotion.

Keywords: academic success, student engagement, student involvement, quality assurance, quality promotion, higher education 


\section{INTRODUCTION}

The articles published in this special issue of the South African Journal of Higher Education (SAJHE) were initially presented at a conference which was organised by the Council on Higher Education (CHE) in February 2020. The theme of the conference was "Enhancing Academic Success through the Involvement of Students in Quality Assurance and Promotion in Higher Education". This article provides a synopsis of the concepts and issues that were central to the discourse around the theme of the conference, and of the main views that emerged from the conference. It is meant to set the scene for the ensuing articles in this special issue and thereby assisting readers with contextualising the articles properly, and identifying the common thread that runs through them.

\section{UNDERSTANDING THE KEY CONCEPTS}

The theme of the conference had four key concepts, namely, "academic success", "student involvement", "quality assurance" and "quality promotion". It is necessary that the meanings attached to these terms as used in this article are explained at the outset.

The term "academic success" refers to the achievement, by students, of the set academic and intellectual development goals. Such achievement is determined primarily by the performance of students in academic assessments such as tests and examinations (Pascarella and Terrenzini 1980). "Academic success" leads to progression in, and completion of the studies that students enrol for. It ultimately leads to the graduation of the students with the relevant higher education qualifications. A closely related term is "student success" which refers not only to the successful completion, by students, of the learning programmes leading to the higher education qualifications that they enrol for, but also to their attainment of the desired skills and competencies, satisfaction, persistence, and acceptable post-qualification performance in the work environment (York, Gibson and Rankin 2015). "Student success" is therefore a broader term as it encompasses achievements during the studies leading to a higher education qualification, as well as in the work environment after students had graduated from higher education institutions.

The term "student involvement" refers to the processes, mechanisms, channels and platforms for allowing students to actively take part in decision-making in the areas of governance and management, quality assurance, and teaching and learning in higher education institutions (Ashwin and McVitty 2015). It is used interchangeably with the term "student engagement" although the latter is broader. While "student involvement" focuses on behavioural aspects of participation, "student engagement" adds emotional and cognitive 
dimensions to participation. It is not just about providing platforms and channels for participation, but also about empowering the students to develop interest in participating, and in understanding the effective ways and means of participation (Zade, Kanzahed and Hassaskhah 2012). The emotional dimension focuses on ensuring that students develop and maintain positive attitude to, interest in, and excitement with their educational experiences. It also focuses on providing conditions that allow students to develop a sense of belonging to their higher education institutions, or to faculties and/or departments (Fredericks, Blumenfeld and Paris 2004). The cognitive dimension empowers students to develop commitment to working hard, determination to finding solutions to challenges, and endurance (Fredericks et al. 2004).

"Student engagement" optimises the experience of students, enhance their learning outcomes as well as the overall performance and reputation of their respective institutions. It also fosters their development towards becoming active and responsible citizens (Cook-Sather, Bovill and Felten 2014). Studies have established causal relationship between "student engagement", on the one hand, and academic and student success, on the other. This means that the more students are engaged or involved, the higher the chances for them to succeed in their studies (Kappe and Van der Flier 2012; Korobova and Starobin 2015).

The term "quality assurance" refers to policies, processes and other mechanisms for ensuring that specified standards or minimum requirements of quality in education, are met (CHE 2016). Quality assurance takes place at two levels. Firstly, at an institutional level, higher education institutions develop and implement policies and mechanisms for ensuring that they fulfil their missions and purposes, and that they meet the relevant requirements of particular educational disciplines and programmes and professions (International Institute for Educational Planning 2010). This institutional-level quality assurance is commonly referred to as internal quality assurance (IQA). It is driven by structures such as the faculty or school boards, academic planning committees, senates and institutional quality assurance units within the higher education institutions. Together, these structures work towards developing and maintaining high internal standards or criteria of quality in the higher education that institutions provide (UNESCO 2019).

Secondly, quality assurance also takes place at national and/or regional levels, driven or overseen by institutions such as quality assurance agencies and professional bodies. These bodies develop minimum quality thresholds, standards or criteria, and assess the operations of higher education institutions, faculties, schools and departments to determine whether or not they meet the predetermined minimum quality thresholds, standards or criteria (Martin and Stella 2007). The form of quality assurance that such agencies and professional bodies are responsible for is commonly referred to as external quality assurance (EQA). In South Africa 
the CHE, Umalusi and the Quality Council for Trades and Occupations (QCTO) are the external quality assurance agencies for higher education, school-level education and the skills development sectors, respectively. South Africa also has statutory and non-statutory professional bodies which are active in external quality assurance. External quality assurance complements internal quality assurance to produce better quality outcomes for a higher education or any other education and training system (Grant 1996).

The term "quality promotion" refers to a range of initiatives that are undertaken to disseminate information and other resources which enable institutions and other role players to create awareness of the need to meet the requirements of quality, and work towards meeting the quality requirements and maintaining a culture of quality. The term "quality promotion" is often conflated with "quality assurance". However, there is a distinction between the two in that "quality assurance" is about assessment and evaluation of the provision of higher education to determine whether or not it meets some predetermined criteria or standards of quality. On the other hand, "quality promotion" is, in the main, about establishing enabling conditions for quality assurance (CHE 2005). Clearly, "quality promotion" interfaces with "quality assurance", and the concepts are two sides of the same coin.

\section{SIGNIFICANCE OF QUALITY ASSURANCE AND PROMOTION}

The National Commission on Higher Education (1996) emphasised that the quality of the South African higher education system is an important lever for ensuring that the higher education system is able to produce graduates who are able to play important roles in the socio-economic development of the country, participate meaningfully in a robust civil society, further scientific and technological innovations, become highly skilled professionals, and contribute to developing solutions to the many challenges that face South Africa as a nation. Accordingly, quality assurance and promotion have become integral components of the higher education delivery value chain.

As discussed earlier, higher education institutions are responsible for internal quality assurance and promotion, while the CHE and professional bodies are responsible for external quality assurance of higher education in the country. Higher education institutions operate at the coal face in the delivery of higher education to students, and are therefore in a better position to take primary responsibility over the quality of provision. However, the external quality assurance and promotion regimen of the CHE is important in setting national quality benchmarks, and overseeing that institutions put in place and maintain systems and processes for assuring the quality of their educational provision (CHE 2001).

It is important to note that while internal quality assurance and promotion arrangements 
have been in existence from the time the first universities were established across Africa (Materu 2007) the role of external quality assurance bodies such as the CHE and professional councils is relatively recent and is sometimes not understood properly, or viewed with suspicion and even disdain (Bailey 2014). It is therefore necessary that the role of external quality assurance is explained.

\section{PERSPECTIVES ON ROLE OF EXTERNAL QUALITY ASSURANCE AND PROMOTION}

There are three perspectives on the role of external quality assurance regimens in higher education. The first perspective views external quality assurance as a mechanism for regulating higher education systems and steering them into particular directions that are determined by national authorities. The external quality assurance bodies "quality control" the educational systems to ensure that the provision of higher education is fit for, and of purpose, and meets associated certain predetermined quality criteria or standards (Vlaamse Universitteiten en Hogescholen Raad 2013). In the majority of countries, the external quality assurance agencies are public bodies that assist governments to use quality as one of the mechanisms for steering the higher education systems. Quality assurance based on this perspective is driven by the moral obligation of ensuring that higher education is not an ivory tower activity that does not make positive contribution to individual students and to the nation at large (Harman and Meek 2000). The significant growth in the private provision of higher education has contributed towards entrenching this perspective of external quality assurance because, left to their devices, private providers of higher education may come up with quality goals that are at variance with the national aspirations (Kruss 2004). This perspective of quality assurance makes it an obligation that national education authorities and quality assurance agencies "quality control" the provision of higher education to ensure that it has strong relationship with national developmental objectives and other imperatives, and that it makes significant contribution towards the realisation of the developmental aspirations. Quality assurance regimes that are based on this perspective emphasise compliance on the part of higher education institutions (Harman and Meek 2000).

The second perspective views external quality assurance as a mechanism for fostering accountability of institutions to students, parents or guardians and/or sponsors of the students; as well as to employers, public authorities and the public at large (Vlaamse Universitteiten en Hogescholen Raad 2013). This perspective is linked to value for money concerns, transparency, public assurance and level of satisfaction that students and stakeholders derive from the higher education provided by institutions. External quality assurance conducted with a predominant 
accountability objective is commonly used to provide assurance to students and other stakeholders that the higher education acquired from the institutions is of good value in relation to the monetary and other resource investment they make into it. The "value" expected includes employability of graduates, enhancement of national pride and reputation, international comparability, and making graduates good patriots (Kis 2005).

The third perspective views quality assurance as developmental in nature and whose purpose is to encourage reflection and continuous improvement. It regards external quality assurance as a tool for empowering institutions to reflect on their execution of the core mandates, identify areas they need to improve on, and design and implement measures to improve. External quality assurance regimes that are based on this perspective emphasise engagements with institutions to assist them to chart and follow trajectories of continuous improvement in teaching and learning and other core higher education activities (Grant 1996). External quality assurance agencies focus on assisting institutions to develop and adopt formal and systematic self-assessment procedures at various levels, ranging from the individual academic, through the departmental and faculty levels, to institutional level. It is premised on the belief that transformative quality improvement occurs more easily when role players in the academic project openly reflect on, and assess their own performances with a view towards continuous improvement (Martin and Stella 2007). Ironically, developmental external quality assurance works more effectively in more mature higher education systems where there are good foundations for quality assurance, and where a quality culture is entrenched (International Institute for Educational Planning 2010). Institutions engage in quality improvement because they see value in it. They do not do so as a matter of compliance with some external regulations.

The three perspectives as briefly discussed above are not mutually exclusive, and therefore most external quality assurance systems tend to have elements of two or all three perspectives (Kis 2005). In South Africa, the National Commission on Higher Education (1996) reflected on the tension between the accountability and developmental or improvement perspectives, and made a choice of, and recommended the improvement quality assurance system as the anchor of the post-apartheid higher education system. Although the National Commission on Higher Education (1996) recommended the improvement-focused quality assurance system, when the Higher Education Quality Committee (HEQC) of the CHE embarked on the process of developing and institutionalising the national external quality assurance system, it opted for a hybrid system that sought to uphold the accountability of higher education provision within the context of a predominantly strong developmental and formative approach (CHE 2001).

\section{THE NATIONAL EMPHASIS ON ACADEMIC AND/OR STUDENT SUCCESS}

The National Commission on Higher Education (1996) made a clarion call for transforming the 
higher education system inherited from the apartheid dispensation into an effective and efficient post-apartheid higher education system that would contribute meaningfully to the realisation of national development goals. Among the key priorities for the transformation of the higher education system was expanding access. Specifically, the National Commission on Higher Education (1996) highlighted the importance of removing barriers to access to higher education so that as many people as possible would be granted access to a full spectrum of opportunities to pursue higher education studies. It also called for the elimination of discriminatory criteria for admission to higher education institutions. Such criteria include race, gender, age, socioeconomic background and the geographic place of origin of applicants for admission to higher education institutions.

Taking its cue from the National Commission on Higher Education (1996), the Education White Paper 3: A Programme for the Transformation of Higher Education (Department of Education 1997) envisioned a transformed, democratic, non-racial and non-sexist system of higher education that, among other priorities, would provide equal access to all that would be eligible for admission to higher education institutions, and facilitate horizontal and vertical mobility of students. It would also focus on improving the quality of teaching and learning; promote the development of flexible learning systems, including open and distance education; produce graduates with the skills and competencies that would be required for developing the country; develop research capacity in higher education institutions; and facilitate a more representative staff component in higher education institutions, which would be sensitive to local, national and regional needs.

Building on the priorities set out in the Education White Paper 3: A Programme for the Transformation of Higher Education (Department of Education 1997), the White Paper for Post-School Education and Training (PSET) (Department of Higher Education and Training 2013) called for expanding access, improved quality and increased diversity of provision. It also emphasised the importance of ensuring that the higher education system would be responsive to the needs of individual citizens and of employers in both public and private sectors, as well as to the broader societal and developmental objectives of the country. Furthermore, it urged for the development and maintenance of stronger and more cooperative relationships between education and training institutions, on the one hand, and the workplace, on the other.

The National Development Plan (National Planning Commission 2012) similarly identified expanding access as a key priority in its vision for a higher education system that would contribute to the development agenda of the nation. It envisaged a seventy percent increase in enrolment of students in universities by 2030 . This would translate into an increase 
from about 950000 students entering universities in 2010 to 1.62 million in 2030.

The nation legitimately expects that the majority, if not all, students who gain access to higher education institutions should be successful in their studies and graduate to play active roles within the economy of the country. Therefore, the emphasis has shifted from simply calling for expanded access, to calling for expanded access and increased success as twin priorities. Expanded access without associated high levels of student success would not assist the country to achieve its developmental goals (Saidi and Chalufu 2020). When the National Commission on Higher Education (1996) and the subsequent post-apartheid higher education policies envisioned an "effective and efficient higher education system", by "efficient" they meant a higher education system that would have higher levels of student success as demonstrated by higher throughput and graduation rates (Essop 2020). Unfortunately, the National Plan for Higher Education (Department of Education 2001) highlighted that the higher education system during the first decade of democracy was still characterised by low graduation rates and high dropout rates which represented a typical inefficient system that has huge waste of resources. The National Plan for Higher Education (Department of Education 2001) therefore flagged the increase in academic and/or student success as a key priority going forward. There have been modest increases in throughput and graduation rates since then (Essop 2020) which underscores the point that the system should continue to place premium priority on improving academic and/or student success. The government, students and other key role players are required to play their respective roles to help improve academic and student success within the higher education system of South Africa.

\section{ENHANCING ACADEMIC SUCCESS THROUGH THE INVOLVEMENT OF STUDENTS IN QUALITY ASSURANCE AND PROMOTION}

The possibility of enhancing academic success through the involvement of students in quality assurance and promotion in higher education is premised on the theory of students as "partners" who should work alongside academics and management staff to formulate missions and purpose of higher education institutions, develop core and co-curricular programmes, develop appropriate learning and teaching platforms, and create conducive institutional climate for the academic project to thrive (Cook-Sather et al. 2014). This theory advances the perspective that students have rights and responsibilities as "higher education citizens", and that they should strive to contribute to the success of their respective institutions as "co-creators" of knowledge and "co-facilitators" of their own learning. In this regard it is important to provide students the opportunity to explore areas that they believe to be significant, to recommend solutions, and to bring about the required changes to themselves, their learning programmes and their institutions 
(Healey, Flint and Harrington 2014).

Earlier on, this article cited studies that established causal relationship between "student engagement", including "student involvement", on the one hand, and academic and student success, on the other (Kappe and Van der Flier 2012; Korobova and Starobin, 2015). This would apply to student involvement in quality assurance and promotion which, as discussed earlier, are globally recognised as vital components of the higher education delivery value chain. However, it is important to emphasise that enhancing academic success through the involvement of students in quality assurance and promotion requires that the students possess good understanding of issues of quality and the processes involved. Such understanding would enable the students to make informed decisions on how they would contribute meaningfully to the quality assurance and promotion processes within institutions and also at national levels. Quality literacy among students would therefore be key because it would not only enhance the involvement of students in quality assurance and promotion, but it would also empower them to shape quality in academic programmes and institutional arrangements (HEQC 2009).

At a more practical level, the Working Group on Student Engagement of the Higher Education Authority of Ireland (2016) characterised different levels of involving students in the higher education delivery value chain. These levels are along a continuum or "ladder" ranging from informing students about the processes (non-participation), through consulting students as the processes are being rolled out (tokenism), to actively involving students in the design, development and execution of the processes. The latter level empowers students to take full ownership of the processes, as well as full control of matters that fall within their capabilities and authority. It is when students are empowered to take full ownership of the processes that the influence of student involvement on student success becomes significant (Saidi and Chalufu 2020).

Closely related to the different levels of involving students in the higher education delivery value chain as discussed by the Working Group on Student Engagement of the Higher Education Authority of Ireland (2016) are three approaches that could be employed to involve students in quality assurance and promotion at institutional level, as identified by Naidoo (2004). The first one is the "student feedback approach" which is premised on the recognition of students as recipients of services and not as active participants. Academics normally seek feedback from students on their learning experiences in specific modules or programmes. The feedback is supposedly used by the academics to improve the contents and delivery of the modules or learning programmes. The drawback of this approach is that, in most cases, the academics do not report back to the students on how they, the departments, the schools or faculties, make use the feedback obtained from the students. Quite often than not, students have 
no idea of how the feedback they provide after the end of each module or learning programme, is utilised by the academics and the institutions (Mbhele and Mokatsane 2020).

The second approach is referred to as "student rights approach". Under this approach the involvement of students in quality assurance and promotion is considered a legal right, particularly in countries where access to quality education is a basic human right enshrined in the national constitutions. Frameworks are therefore developed by the national quality assurance agencies and individual higher education institutions, to give effect to this right by fostering and facilitating the involvement of students in quality assurance and promotion. However, in relation to higher education, such rights are not universal. In South Africa, for instance, the Bill of Rights specifies that everyone has a right to quality basic education, but this right does not extend to higher education. The implication of this is that the student rights approach to fostering student involvement in quality assurance and promotion, cannot be enforced in South Africa. The ideals of academic freedom and institutional autonomy further limit the possibility of effectively implementing national quality assurance frameworks that advocate the involvement of students in quality assurance and promotion, as a right (Naidoo 2004).

The third approach holds students as active co-constructors of the processes of quality assurance and promotion. Naidoo (2004) asserts that students need to be encouraged to review and shape the higher education delivery environment as active role players and co-constructors of quality, who are empowered to be involved meaningfully in developing and implementing quality assurance and promotion policies and processes. However, this requires that information on quality assurance and promotion is provided to the students, that the students are capacitated through nuanced quality literacy initiatives, and that they are able to interpret the information provided to them in a manner that allows them to make judgements about quality (Naidoo 2004).

Cele (2007) supports the involvement of students as co-constructors of quality. He expressed the view that such involvement would contribute to the enhancement of quality in higher education institutions in various ways. Firstly, it would provide space for students to voice their experiences and judgements about quality in programmes and institutional arrangements. Secondly, it would bring to the attention of institutional decision-makers a direct form of feedback on the quality of the total learning experience accorded to, and received by students. Thirdly, it would encourage a dialogue between students, academics and institutional decision-makers on strategies and mechanisms that can be adopted to improve quality. Fourthly, it would assist students to understand the basic language of the quality discourse and the nomenclature of quality assurance, which would enable them to assess the accuracy of the course information they receive during the process of registering for courses, modules or 
learning programmes.

\section{CONTRIBUTIONS OF THE CHE CONFERENCE TO THE DISCOURSE}

The conference organised by the CHE provided a platform for a critical discourse on the need for, and approaches to mainstreaming the involvement of students in quality assurance and promotion activities within higher education in South Africa. The conference, which was held from 26 to 28 February 2020, had sessions for panel discussions in addition to plenary and paper presentation sessions. The proceedings of the conference provide a rich addition to the discourse on enhancing academic success through student involvement in quality assurance and promotion. Priorities for deepening the discourse have been distilled from the proceedings and are discussed in the ensuing paragraphs.

The institutionalisation of quality assurance and promotion is one of the prominent global trends in higher education (International Institute for Educational Planning 2010). Several factors have led to an increase in the development and implementation of internal and external quality assurance regimes in higher education. These include the demand for more accountability and higher levels of efficiency in respect of public funds that are invested in higher education; the growing social demand for, and the consequent expansion of higher education systems; the increase in competing demands for public funds with the resultant decline in funds invested in higher education; and greater stakeholder scrutiny of higher education processes and outcomes (CHE 2001).

In South Africa, quality assurance and promotion, funding of higher education and policy instruments are the important mechanisms for steering the higher education system in a direction in which it is expected to become a key contributor to the achievement of the development goals of the country (National Commission on Higher Education 1996). The critical role of quality assurance and promotion in higher education therefore cannot be overemphasised (CHE 2001).

The dominant view at the conference was that internal and external quality assurance and promotion programmes need to be supported fully, not from the point of view of compliance, but more from views that they assist in ensuring that the higher education offered in the country is fit for, and of purpose; demonstrates value for money invested in it by the government, families and sponsors; contributes to transformation within and outside higher education; and protects students as "consumers" and/or beneficiaries of higher education as an essential service.

Higher education has traditionally been considered as a "public good" (Davids and Waghid 2020; Marshall 2016). However, the contemporary world is also witnessing an 
increasing trend towards privatisation of higher education. One of the factors that are catalysing this trend is the inability of public universities to meet the ever-growing demand for higher education. The other factor is the common understanding that the benefits of higher education largely accrue to the individual, whether it is about being employed or becoming a good citizen (Stella 2004). Unfortunately, the increasing global trend towards privatisation of higher education has brought to the fore concerns about quality because it has been observed that privatisation has the effect of making higher education more unequal in terms of quality of provision (International Institute for Educational Planning 2010). Furthermore, public higher education institutions are also undergoing a major "quasi-privatisation" process through increasing reliance on cost sharing arrangements and income generation measures, which have the same effect of diverting the focus of the institutions from quality of provision to quantity of students and the associated finance-related measures of institutional performance (Stella 2004). There was unanimity at the conference that internal and external quality assurance and promotion initiatives are critical for ensuring that students are protected from the possible negative effects of privatisation of higher education, on quality.

Experience from interventions that seek to benefit communities or other groups of beneficiaries has demonstrated that better results are obtained when the intended beneficiaries are involved in the design and implementation of the intervention programmes. In the same manner, the involvement of students in quality matters is of paramount importance, since students are at the receiving end of the teaching and learning experience (HEQC 2009). Students need to have a good understanding of issues of quality and the processes involved because such understanding facilitates the creation of conditions for their academic success. The involvement of students in quality assurance and promotion processes empowers students to define and shape quality in academic programmes and institutional arrangements in ways that contribute to success in their academic pursuits (Baijnath 2020). Participants at the conference spoke with one voice in expressing the need for the "student voice" to be heard in quality assurance and promotion. However, there was a significant view that it is necessary for the professionals in quality assurance and promotion, both from the CHE as well as at institutional levels, to make quality assurance and promotion less of an exclusive area or field of practice. There were calls to lift the veil off quality assurance and promotion, and make the quality assurance and promotion processes more transparent and inclusive. It was emphasised that, not only should students be involved, academics and professional support staff at all levels within higher education institutions should also be active participants because every activity that takes place in institutions has a bearing on quality of higher education.

Although there was general acceptance at the conference of the need to involve students 
in quality assurance and promotion initiatives, it was also accepted that the translation of this need into practice had been both sporadic and ad hoc. Based on available literature, it would appear that in most higher education institutions there is minimal, if any, involvement of students in quality assurance and promotion initiatives (HEQC 2009). Students are involved in many governance structures within their respective higher education institutions, but their overall participation in quality assurance and promotion is minimal, and in some cases, nonexistent. Furthermore, in those institutions where there are attempts to involve students in quality assurance and promotion initiatives, the students sit in faculty or school boards and in the committees of senate when new and/or reviewed learning programmes are discussed for approval. However, by and large, the participation of students in these structures has had questionable value. This is because the discussions that take place in these academic structures are generally beyond the grasp of the student representatives. This constrains them from making constructive contributions in the deliberations (Saidi and Chalufu 2020). In this regard, there was unanimity at the conference that it is essential that programmes should be developed and implemented aimed at making students understand and appreciate what quality assurance and promotion entail, how these affect them, and how they can play constructive roles in them. Similarly, the roles of the students in the quality assurance and promotion processes should be clearly defined. Such programmes would help in empowering the student representatives to be able to make meaningful contribution in deliberations that take place within the academic structures that they serve on.

The conference reflected on the practice of requiring students to evaluate courses or modules by responding to end of module or course questionnaires. The dominant view was that, in most institutions, the purpose of those questionnaires is not explained to the students. Similarly, most of the questions on the questionnaires require "yes" or "no" answers, which means students cannot provide qualitative information about their assessment and judgement of the courses or modules in question. Furthermore, as discussed earlier, it is not clear if the academics make use of the information provided on the questionnaire because the courses or modules are rarely improved in anyway. The very same courses or modules are offered continuously in the same shape and form notwithstanding any constructive criticism that students might have provided in their responses to the course or module evaluation questionnaires. The conference therefore questioned the value of the traditional questionnaire feedback approach to involving students in quality assurance and promotion. It would appear therefore that academics prepare the questionnaires and request students to complete them simply to demonstrate that they have complied with some institutional quality assurance policies that require that students evaluate courses (Mbhele and Mokatsane 2020). The 
conference made an impassionate plea for this common practice to change if the involvement of students is expected to make meaningful contribution towards improving the quality of courses and modules in higher education.

Another dominant view at the conference was that, clearly, there are institutional barriers to the participation of students in quality assurance and promotion, and these barriers include institutional policies. These policies would have to change if at all students are to be earnestly involved in quality assurance and promotion. The conference also highlighted the importance of students taking a lead in finding means and ways of eliminating the barriers to their meaningful involvement in quality assurance and promotion. The conference reflected that part of the demands of students during \#FeesMustFall campaigns in 2015 and 2016 was that the curricula should be transformed. In particular, the student demanded expunging from the curricula those aspects that reflect and entrench colonial hegemony, and replacing them with elements that would promote students to develop pride in their African heritage and identity, and make them yearn to find African solutions to African challenges (Legodi 2020; Rapanyane 2020). The conference noted that the curriculum is at the centre of both internal and external quality assurance and promotion regimes in South Africa, and that it is essential to maintain the momentum created in the discourse on decolonisation of the curricula because, through it, students are likely to see and appreciate the necessity of being involved in quality assurance and promotion programmes at the institutional and national levels. When this happens, students would then become partners in the design of curriculum, selection and review of content, teaching and learning, and generally in the quality assurance and promotion, particularly at institutional level (Botha and Steyn 2020; Sundani 2020). The conference called on the portfolios of Student Affairs in higher education institutions to facilitate a more holistic approach to student engagement which should include engagement on academic and quality assurance and promotion matters.

There was unanimity at the conference that students are also not involved in the quality assurance and promotion processes of the $\mathrm{CHE}$, and that the majority of students are not even aware of the roles and responsibilities of the CHE. Currently there are no platforms available for students to be involved in, and influence the external quality assurance and promotion processes of the CHE (HEQC 2009). By contrast, the conference made an observation that there are recognised structures and platforms for student engagement on political, governance and decision-making matters at a national level. The view was that while structures and platforms for student engagement on political, governance and decision-making matters at a national level serve a good cause of advancing the democratic rights of students, their limitation is that they do not extend to the core purpose of higher education which includes knowledge generation, 
dissemination and application. The conference therefore called on students to take a lead in demanding similar structures and platforms for engaging in quality assurance and promotion, and other processes associated with the core functions of higher education institutions, which include teaching and learning, research, and engaged scholarship or community engagement.

Participants at the conference unanimously called on students to demand to be involved in the development and implementation of the nation-wide external quality assurance and promotion frameworks of the CHE as part of the transformation of higher education for the purpose of improving student success. The conference expressed the view that students should be integral to the discourse about defining quality in the African context, and playing active roles in developing and implementing quality assurance and promotion frameworks. The participants at the conference urged students to take a lead in posing more questions about the epistemic origins of knowledge in order to establish what and whose knowledge is being disseminated in higher education institutions. This would be necessary to ignite interest in the discourse around building universities that are grounded in the authentic African reality based on structures that are inherently African (Monnapula-Mapesela 2020). The conference called upon the CHE to come to the party by ensuring that it would become more visible and that it would communicate clearly on its mandate to assure and promote quality in higher education.

The conference emphasised that meaningful and value-adding involvement of students in quality assurance and promotion would require changes to the system and processes that incorporate student-lecturer partnerships. Such relationships should be based on a transformative pedagogical approach that calls for listening attentively to the voice of students. This should inspire and influence new approaches for student involvement in quality assurance and promotion (Pather 2020). Higher education institutions should educate and train staff, student leadership and the broader student body, on quality issues. They should identify and define the roles of students in the processes, and train them on how to play those roles effectively. The CHE and higher education institutions should provide relevant information to students and establish clear rules of engagement.

There were also views that the development and implementation of student mentoring programmes in quality assurance and promotion could facilitate the transfer of the relevant knowledge and information to students, while also increasing the chance of buy-in from the students. A keynote speaker passionately argued for the use of mentoring as a mechanism for igniting the interest of students to be involved in quality assurance and promotion (Dzvimbo 2020).

Another dominant view at the conference was that, in the contemporary digital world, technology could be leveraged to expand the reach of student involvement in quality assurance 
and promotion. Lottering (2020), for example, made a case for the use of digital technology through social media to expand the reach of student involvement especially within remote teaching and learning environments. Coincidently, barely two weeks after the conference, the coronavirus pandemic forced higher education institutions to close their campuses and embark on remote teaching and learning. Globally, the increase in remote teaching and learning arrangements in the wake of the coronavirus pandemic starkly exposed the need to find alternative ways of engaging students more meaningfully on academic matters, including in quality assurance and promotion, as well as in non-academic matters including student wellness, morbidities and deaths within their families, and access to proper study spaces (Gill 2020).

\section{CONCLUSION}

The post-apartheid policies on higher education envisioned a transformed, effective and efficient higher education system. Key characteristics of that system include expanding access and improving student success. The post-apartheid policies on higher education also recognise quality as one of the mechanisms for steering the higher education system in the country. Quality assurance and promotion are acknowledged as integral components of the higher education delivery value chain, and that the involvement of students in quality assurance and promotion activities at institutional and national levels would contribute to enhancing academic and student success. Currently there are barriers to student involvement in quality assurance and promotion and it is critical that necessary steps should be taken to eliminate the barriers. Students need to take a lead in eliminating the barriers because the experience from the \#FeesMustFall campaign suggests that when they take a lead on a matter that concerns them, the authorities tend to listen seriously. However, it is important to understand that meaningful and value-adding involvement of students in quality assurance and promotion would require changes to the system and processes that govern student-lecturer relationships. It is critical that such relationships should be based on a transformative pedagogical approach that calls for listening attentively to the voice of students. Furthermore, in the contemporary digital world, technology could be leveraged to expand the reach of student involvement in quality assurance and promotion.

\section{REFERENCES}

Ashwin P. and D. McVitty. 2015. The meanings of student engagement: Implications for policies and practices. In The European higher education area: Between critical reflections and future policies, ed. A. Curaj, L. Matei, R. Pricopie, J. Salmi and P. Scott. Cham: Springer

Baijnath, N. 2020. Foreword in Quality Promotion Conference Handbook: 26 to 28 February 2020. 
Pretoria: CHE.

Bailey, B. 2014. The role and functions of Higher Education Councils and Commissions in Africa: A case study of the South African Council on Higher Education. Cape Town: Centre for Higher Education Transformation.

Botha, A. and A. Steyn. 2020. Student-faculty partnership in design: Evaluating a co-creation practice and sharing of findings within the South African higher education context. Paper presented at the Quality Promotion Conference: 26 to 28 February 2020. Pretoria: CHE.

Cele, N. 2007. The role of student support services in promoting and enriching the positive experience for learners. Paper Presented at the Conference of the National Association of Student Development Practitioners, 3-5 October 2007. Cape Town: Cape Peninsula University of Technology.

CHE see Council on Higher Education

Cook-Sather, A., C. Bovill and P. Felten. 2014. Engaging students as partners in learning and teaching: A guide to faculty. San Francisco: Jossey-Bass.

Council on Higher Education. 2001. Higher Education Quality Committee Founding Document. Pretoria: CHE.

Council on Higher Education. 2005. Towards a framework for quality promotion and capacity development in South African higher education. Pretoria: CHE.

Council on Higher Education. 2016. A good practice guide for the quality management of short courses offered outside of the higher education qualifications sub-framework. Pretoria: CHE.

Davids, N. and Y. Waghid. 2020. Tracking five years of teacher education enrolment at a South African university: Implications for teacher education. South African Journal of Higher Education 34(2): $2-16$.

Department of Education. 1997. Education White Paper 3: A Programme for the Transformation of Higher Education. Pretoria: Government Printers.

Department of Education. 2001. The National Plan for Higher Education. Pretoria: Department of Education.

Department of Higher Education and Training. 2013. White Paper for Post-School Education and Training (PSET). Pretoria: Department of Higher Education and Training.

Dzvimbo, K. P. 2020. The implausible dream: Rethinking the way we think about discourse practices in quality assurance and tertiary education on the African continent. Paper Presented at the Quality Promotion Conference: 26 to 28 February 2020. Pretoria: CHE.

Essop, A. 2020. The changing size and shape of the higher education system in South Africa, 20052017. Johannesburg: University of Johannesburg.

Fredericks, J. A., P. C. Blumenfeld and A. H. Paris. 2004. Student engagement: Potential of the concept, state of the evidence. Review of Educational Research 74(1): 59-109.

Gill, J. 2020. Improve, adapt, overcome. Times Higher Education 2(453): 2-15 April 2020.

Grant, H. 1996. Quality assurance for higher education: Developing and managing quality assurance for higher education systems and institutions in the Asia and Pacific. Bangkok: Asia-Pacific Centre of Education and Innovation for Development.

Harman, G. and V. L. Meek. 2000. Repositioning quality assurance and accreditation in Australia higher education. Canberra: Commonwealth of Australia.

Healey, M., A. Flint and K. Harrington. 2014. Engagement through partnerships: Students as partners in learning and teaching in higher education. York: The Higher Education Academy.

HEQC see Higher Education Quality Committee

Higher Education Quality Committee. 2009. A baseline study on student participation in quality assurance. Final Report of a research work undertaken by P. M. Chiroro and N. Shabalala on behalf of the CHE. Pretoria: CHE. 
International Institute for Educational Planning. 2010. Making basic choices for external quality assurance systems. Paris: UNESCO.

Korobova, N. Y. and S. S. Starobin. 2015. A comparative study of student engagement, satisfaction and academic success among international and American students. Journal of International Students 5(1): 72-85.

Kappe, F. R. and H. van der Flier. 2012. Predicting academic success in higher education: What is more important than being smart? European Journal of Psychology 27: 605-619.

Kis, V. 2005. Quality assurance in tertiary education: Current practices in OECD countries and a literature review on potential effects. OECD Thematic Review of Tertiary Education. Paris: OECD.

Kruss, G. 2004. Chasing credentials and mobility: Private higher education in South Africa. Pretoria: HSRC Press.

Legodi, L. T. 2020. Towards understanding the \#FeesMustFall as a "leaderless" student movement in South Africa. Kagisano, Research Journal of the CHE 12: 46-59.

Lottering, R. 2020. Using social media to enhance academic success at a selected higher education institution in South Africa. Paper Presented at the Quality Promotion Conference: 26 to 28 February 2020. Pretoria: CHE.

Marshall, S. 2016. Quality as sense-making. Quality in Higher Education 22(3): 213-227.

Martin, M. and A. Stella. 2007. External quality assurance in higher education: Making choices. Paris: UNESCO.

Materu, P. N. 2007. Higher education quality Assurance in Sub-Saharan Africa: Status, challenges, opportunities and promising practices. Washington: World Bank.

Mbhele, S. P. and S. T. Mokatsane. 2020. The significance of student involvement in quality assurance as a means of promoting academic success. Paper presented at the Quality Promotion Conference: 26 to 28 February 2020. Pretoria: CHE.

Monnapula-Mapesela, M. L. E. 2020. Perspectives on quality promotion in the South African higher education context: Challenges and opportunities for students. Paper Presented at the Quality Promotion Conference: 26 to 28 February 2020. Pretoria: CHE.

Naidoo, P. 2004. Student quality literacy and empowerment. Paper presented at the Second Global Forum on International Quality Assurance, Accreditation and the Recognition of Qualifications in Higher Education - Widening Access to Quality Higher Education. Paris: UNESCO, 28-29 June 2004.

National Commission on Higher Education. 1996. A framework for transformation: A Report of the National Commission on Higher Education. Pretoria: NCHE.

National Planning Commission. 2012. National Development Plan 2030. Pretoria: The Presidency.

Pascarella, E. T. and P. T. Terenzini. 1980. Predicting freshmen persistence and voluntary dropout decisions. The Journal of Higher Education 51(1): 60-75.

Pather, K. 2020. Moving from a traditional to a transformative pedagogical approach that enhances active student engagement. Paper Presented at the Quality Promotion Conference: 26 to 28 February 2020. Pretoria: CHE.

Rapanyane, M. B. 2020. Revisiting student engagement in a comprehensive public university in South Africa from an Afrocentric point of view. Kagisano, Research Journal of the CHE 12: 93-101.

Saidi, A. and S. Chalufu. 2020. Student governance and engagement for academic success: An overview. Kagisano, Research Journal of the CHE 12: 1-14.

Stella, A. 2004. Quality assurance mechanisms in higher education in the Asia-Pacific. Paris, UNESCO

Sundani, N. D. 2020. The impact of student-teacher relationship on good decision-making and quality promotion in higher education. Paper Presented at the Quality Promotion Conference: 26 to 28 February 2020. Pretoria: CHE. 
Vlaamse Universitteiten en Hogescholen Raad. 2013. Manual for the external quality assurance in Flemish Higher Education. Ghent: VLUHR.

UNESCO. 2019. Quality and employability in higher education: Viewing internal quality assurance as a lever for change. Paris: International Institute of Educational Planning.

Working Group on Student Engagement of the Higher Education Authority of Ireland. 2016. Enhancing student engagement in decision-making. Dublin: Higher Education Authority of Ireland

York, T. T., C. Gibson and S. Rankin. 2015. Defining and measuring student success. Practical Assessment, Research and Evaluation 20(5): 1-20.

Zade, M. M., A. A. Kanzahed and J. Hassaskhah. 2012. The relationship between internal forms of engagement (cognitive-affective) and academic success across years of study. Issues in Language Teaching 2: 251-272. 